\title{
TRI SPLETNE APLIKACIJE O SLOVENSKIH NAREČJIH
}

\author{
Rok MRVIČ
}

Inštitut za slovensko narodopisje, ZRC SAZU

\section{Špela ZUPANČIČ}

Filozofska fakulteta, Univerza v Ljubljani

Mrvič, R., Zupančič, Š. (2021): Tri spletne aplikacije o slovenskih narečjih. Slovenščina 2.o, 9(1): 236-261.

DOI: https://doi.org/10.4312/slo2.0.2021.1.236-261

Potreba po večji prisotnosti narečnih vsebin na spletu in njihovi interaktivni multimedijski predstavitvi, predvsem strokovno zasnovanih dialektoloških virov in orodij, je spodbudila interdisciplinarno sodelovanje različnih fakultet Univerze v Ljubljani, zlasti Filozofske fakultete (FF) in Fakultete za računalništvo in informatiko (FRI), ki je v letih 2017 in 2018 obrodilo sadove v obliki treh prostodostopnih in odprtokodnih spletnih aplikacij o slovenskih narečjih - to so Slovenski narečni atlas (SNA, 2017), Interaktivna karta slovenskih narečnih besedil (IKNB, 2018) in Slovar starega orodja v govoru Loškega Potoka (SSOLP, 2018). Članek v prvem delu prinaša splošen pregled slovenskih spletnih dialektoloških virov in orodij, $\mathrm{v}$ drugem delu pa podrobnejšo predstavitev funkcionalnosti navedenih treh aplikacij, ki so uporabnikom trenutno na voljo. V diskusijskem delu pregleda je izpostavljen del okoliščin nastanka obravnavanih aplikacij in z nastankom povezanih omejitev, nakazane pa so tudi možne rešitve, ki bi jih veljalo preudariti za zagotovitev njihovega dolgoročnega razvoja.

Ključne besede: slovenska narečja, spletna aplikacija, narečni atlas, narečni slovar, interaktivna karta 
$\mathrm{Z}$ digitalizacijo in hitrim tehnološkim razvojem se je zlasti v zadnjem desetletju v slovenski dialektologiji pojavila potreba po prenosu jezikovnih orodij in priročnikov na splet. $\mathrm{V}$ sodobnih slovenskih narečnih govorih prihaja do velikih sprememb - tako v zemljepisnem prostoru kot v novih funkcijah oz. položajih rabe (Smole, 2019, str. 21) -, zanimanje zanje v sodobni slovenski družbi pa vse bolj narašča. ${ }^{1}$ Spremembe so v zadnjih petih letih spodbudile razvoj več spletnih orodij, ki omogočajo strokovno in ciljno objavo narečnega gradiva, namenjenega zlasti jezikoslovcem in študentom, vendar poskušajo ob tem k uporabi pritegniti tudi širšo javnost. Med taka orodja uvrščava aplikacije Slovenski narečni atlas (SNA), Interaktivna karta slovenskih narečnih besedil (IKNB) in Slovar starega orodja v govoru Loškega Potoka (SSOLP), ki so nastale v interdisciplinarnem sodelovanju različnih fakultet Univerze v Ljubljani. ${ }^{2}$ Vse tri spletne aplikacije so prostodostopne, odprtokodne, ${ }^{3}$ interaktivne in rastoče. $\mathrm{V}$ drugem poglavju strneva splošen pregled slovenskih dialektoloških virov in orodij, v tretjem poglavju pa po kronološkem zaporedju od najstarejše (SNA, 2017) do najmlajše (SSOLP, 2018) nadaljujeva s predstavitvijo bistvenih informacij o aplikacijah SNA, IKNB in SSOLP, ${ }^{4}$ in sicer z vidika funkcionalnosti, ki so uporabnikom trenutno na voljo.

1 Na večje zanimanje za narečja vpliva preplet več družbenih dejavnikov, povezanih z jezikovno identiteto narečnih govorcev, ki se je z digitalizacijo družbe začela jasno odražati v obliki diskusijskih skupin, forumov in predstavitvenih strani krajev, pokrajin in njihovih narečnih govorov na sodobnih družbenih omrežjih, kot sta Facebook in Instagram. O nezanemarljivem vplivu spletnih mest manifestacije narečne zavesti pričajo podatki o številu sledilcev oz. članov tovrstnih skupin in podatki o njihovi dejavnosti, na podlagi samoiniciativnih objav narečnega gradiva (domnevno narečno specifičnih frazemov, pregovorov, kletvic, pozdravov, vzklikov ipd.) pa so se začeli vzpostavljati tudi turistični projekti ter samostojne publikacije, ki so izšle z namenom predstavitve narečnih prvin širši javnosti.

2 Pri izdelavi IKNB in SNA sta sodelovali Filozofska fakulteta Univerze v Ljubljani (FF) in Fakulteta za računalništvo in informatiko Univerze v Ljubljani (FRI), pri izdelavi SSOLP pa še Naravoslovnotehniška fakulteta Univerze v Ljubljani (NTF).

3 Izvorne kode predstavljenih aplikacij so objavljene v repozitoriju Bitbucket.

4 Pri pripravi vsebine aplikacij so v okviru seminarjev in projektov ter zaključnih študijskih del sodelovali študenti Oddelka za slovenistiko Filozofske fakultete Univerze v Ljubljani. Zapis narečnega gradiva v navedenih aplikacijah je bil pripravljen z vnašalnim sistemom ZRCola (http://zrcola.zrc-sazu.si), ki ga je na Znanstvenoraziskovalnem centru SAZU v Ljubljani (http://www.zrc-sazu.si) razvil Peter Weiss. 


\section{SPLETNI DIALEKTOLOŠKI VIRI IN ORODJA}

Dialektološki viri5 ${ }^{5}$ so lahko 1) prvotno objavljeni v tiskani obliki in kasneje digitalizirani ter prilagojeni za objavo na spletu ali 2) izhodiščno digitalni, torej namensko razviti za spletno objavo. Med slednje spadajo tudi spletne aplikacije, o katerih v kontekstu tega besedila govoriva kot o specializiranih jezikoslovnih oz. dialektoloških orodjih, ki izkoriščajo različne možnosti digitalnega medija, s čimer uporabniku omogočajo interaktivno spoznavanje narečnega gradiva na več ravneh. V Sloveniji so dialektološke vsebine spletnih jezikovnih virov v veliki večini rezultat strokovnega in znanstvenega preučevanja, izjemoma pa tudi ljubiteljskega zbiranja narečnega gradiva. ${ }^{6} \mathrm{~V}$ nadaljevanju je predstavljen kratek pregled nekaterih slovenskih spletnih narečnih virov, ki so prosto dostopni in pri izdelavi katerih so sodelovali dialektologi, torej virov, ki naj bi uporabnikom nudili relevantne, strokovno pregledane vsebine.

\subsection{Spletni dialektološki viri}

Med temeljne slovenske digitalizirane dialektološke vire uvrščava pet narečnih slovarjev in Slovenski lingvistični atlas (SLA) - do vseh lahko dostopamo na spletnem portalu Fran.7 Digitalizirane različice slovarjev so uporabnikom portala Fran na voljo predvsem v obliki faksimilov, ${ }^{8}$ kar jih v primerjavi s

5 Pojem spletni dialektološki vir uporabljava kot krovni pojem za vse oblike virov dialektološko obdelanih jezikovnih podatkov (slovarjev, atlasov, korpusov, interaktivnih kart), ki so dostopni na spletu.

6 Pregled trenutno dostopnih spletnih virov pokaže, da na izbiro vrste končnega prikaza zbranega narečnega gradiva vpliva strokovno znanje zbirateljev takega gradiva. Z izdelavo narečnih slovarjev se npr. ukvarjajo tudi nejezikoslovci (rezultate njihovega dela, zlasti na spletu, zaradi manjkajočih leksikografskih podatkov pogosteje obravnavamo kot zbirke narečnih besed in jih zato v najin pregled ne uvrščava, prim. Benko, 2016, str. 127), medtem ko prikaz narečnega gradiva v atlasu ali na zemljevidu ostaja v domeni dialektologov. Zbiranje narečnega gradiva je v vsakem primeru (tudi če pri tem ne sodelujejo dialektologi) pomembno, saj lahko zbrano gradivo, še posebej posneto, predstavlja osnovo za nadaljnje dialektološke raziskave. Kot vir jezikoslovnih raziskav lahko služi tudi gradivo, zbrano v okviru etnološkega in folklorističnega dela (gl. Ivančič Kutin, 2017, str. 65-69).

7 Na spletu najdemo tudi monografijo Besedotvorni atlas slovenskih narečij: Kulturne rastline (Kumin Horvat, 2018), ki je izšla tako v tiskani kot v digitalni obliki.

8 Prvotno tiskani slovarji pred objavo na spletu niso šli skozi proces optičnega prepoznavanja znakov (ang. optical character recognition, OCR), ki bi uporabnikom omogočalo lažje in bolj ciljno usmerjeno iskanje po gradivu. 
spletnimi slovarji dela precej neprijazne za uporabo, saj uporabniku znotraj enega okna v brskalniku ni omogočen takojšen vpogled v vsebino slovarskega sestavka - slednjo uporabnik najde na ločeno objavljenih slovarskih straneh v formatu PDF, ki so v Franovi spletni bazi povezane z vsemi slovarskimi gesli, ki jih vsebujejo. V tej obliki povezav gesel s slovarskimi stranmi so uporabnikom dostopni Črnovrški dialekt (Tominec, 2015), ${ }^{9}$ obsežen, abecedno urejen slovar, ki prinaša leksiko črnovrškega narečja, Slovar govorov Zadrečke doline med Gornjim Gradom in Nazarjami $(A-H)$ (Weiss, 2015) ${ }^{10}$ ter Slovar bovškega govora (Ivančič Kutin, 2015). ${ }^{11}$ Gesla Slovarja govorov Zadrečke doline med Gornjim Gradom in Nazarjami $(A-H)$ ter Slovarja bovškega govora so tako kot v Tominčevem slovarju glasovno poknjižena, slovarski sestavki pa so v primerjavi s sestavki Črnourškega dialekta bolj podrobno in enotno strukturirani. Weiss je pri tem natančnejši kot Ivančič Kutin, vendar je lahko njegov slovar za splošnega uporabnika prav zato zahtevnejši.

Poleg narečnih slovarjev sta na spletišču Fran vključena tudi oba zvezka Slovenskega lingvističnega atlasa $(2014,2016)^{12}$ - »atlas[a], ki obsega celoten slovenski jezikovni prostor in predstavlja temeljno delo slovenske dialektologije in geolingvistike« (Bon, 2018, str. 42). Uporabniška izkušnja iskanja po atlasu je delno podobna izkušnji iskanja po digitaliziranih slovarjih, saj lahko uporabnik do gradiva dostopa prek posameznih datotek PDF. ${ }^{13}$ Razlika je v tem, da je gradivo za atlas šlo skozi proces optičnega prepoznavanja znakov, kar uporabniku olajša pregledovanje komentarjev, kart in gradiv h kartam za posamezne lekseme. Atlas je bolj kot splošnim

9 Črnovrški dialekt: Kratka monografija in slovar je ob izdaji leta 1964 predstavljal »napredek v slovenski dialektologiji, saj smo imeli pred njim le rokopisne zbirke« (Benko, 2016, str. 126).

10 Slovar govorov Zadrečke doline med Gornjim Gradom in Nazarjami: Poskusni zvezek $(A-H)$ je bil v tiskani obliki objavljen leta 1998 in je predstavljal »prvi slovenski model za izdelavo znanstvenega sinhronega enonarečnega razlagalnega slovarja « (Benko, 2016, str. 126).

11 Slovar je v tiskani obliki izšel leta 2007.

$12 S L A$ 1: Človek (telo, bolezni, družina) je v tiskani izdaji izšel leta 2011 in v digitalni leta 2014, SLA 2: Kmetija pa je v tiskani in digitalni obliki izšel leta 2016.

13 Uporabnik lahko dostopa do komentarjev o posameznih knjižnih leksemih z ustreznicami v različnih narečjih, do kart z grafičnim prikazom narečnih leksemov in do gradiv h kartam, ki vsebujejo podatke o tem, kakšni so narečni izrazi za določen knjižni leksem v posameznih raziskovalnih točkah. 
uporabnikom namenjen strokovnjakom in študentom jezikoslovnih smeri; za ustrezno uporabo atlasa je namreč potrebno osnovno dialektološko predznanje, da lahko uporabnik s kart in iz priloženih komentarjev pridobi iskane podatke.

Na spletišču Fran se nahajata tudi Kostelski slovar (Gregorič, 2015) (14 $^{14}$ Slovar oblačilnega izrazja ziljskega govora v Kanalski dolini (Kenda-Jež, 2019). ${ }^{15}$ Kostelski slovar je bil prvotno izdan v tiskani obliki, njegova postavitev na splet pa se bistveno razlikuje od spletnega prikaza že omenjenih digitaliziranih slovarjev. Uporabnik namreč do slovarskih sestavkov v brskalniku dostopa neposredno na spletnem mestu slovarja - tj. s klikom na izbrano geslo -, ne pa več prek dokumenta digitalizirane strani iz knjige, ki vsebuje določeno geslo. Spletni slovarski sestavek v Kostelskem slovarju je oblikovan pregledno in je po leksikografski zasnovi slovarske mikrostrukture podoben slovarskim sestavkom, ki jih prinaša slovar Barbare Ivančič Kutin. Korak naprej v izrabi možnosti, ki jih ponuja spletni medij, predstavlja spletni slovar Karmen Kenda-Jež. Glavna odlika slovarja je, da ob narečnih zapisih vsebuje zvočne posnetke narečnega gradiva - na ta način slovar po besedah avtorice funkcionira kot »govoreči slovar « (Kenda-Jež, 2019, str. 2), kar je bil del načrtovane slovarske strukture že od samega začetka. Slovarski sestavki, zasnovani natančneje kot v Kostelskem slovarju, imajo pregledno podobo, ki vključuje slovnične podatke in pregibalne vzorce uslovarjenih leksemov (glede na zbrano narečno gradivo) ter pojasnila v pojavnih okencih ob kazalcu miške, ${ }^{16}$ ki ne zahtevajo tako podrobnih legend znakov in uvodnih pojasnil krajšav in ikon. To splošnemu uporabniku omogoča enostavnejšo uporabo slovarja v primerjavi s sestavki slovarjev Weissa in Ivančič Kutin. Za razliko od ostalih omenjenih slovarjev, ki so zasnovani kot splošni narečni slovarji, je slovar Karmen Kenda-Jež tematski narečni slovar.

14 Avtor slovarja je Jože Gregorič, njegovo gradivo pa so urejali Sonja Horvat, Ivanka Šircelj-Žnidaršič in Peter Weiss. Slovar je bil v tiskani obliki objavljen leta 2014.

15 Slovar, ki je bil razvit za objavo v spletni obliki, temelji na knjižnih izdajah monografije Shranli smo jih $v$ bančah: Slovarski prispevek $k$ poznavanju oblačilne kulture $v$ Kanalski dolini - Contributo lessicale alla conoscenza dell'abbigliamento in Val Canale (Kenda-Jež, 12007, 22015).

16 Npr. metapodatki o terenskem delu, kot so začetnice imena in priimka informatorjev ter letnice njihovega rojstva. 
Zvočni posnetki so vključeni tudi v slovar Narečna bera, ki se nahaja na samostojnem spletnem mestu (Benko, 2013), ${ }^{17}$ vendar za razliko od slovarja oblačilnega izrazja ne pri vseh slovarskih sestavkih, imajo pa posamezni sestavki dodane celo videoposnetke. Iskanje po slovarju je od zgoraj navedenih slovarjev najenostavnejše in najpreglednejše. ${ }^{18}$ Narečna bera prinaša veliko narečnega ponazarjalnega gradiva, pri nekaterih geslih tudi zvočne posnetke, videoposnetke in slikovno gradivo, vendar zgradba slovarskih sestavkov v marsičem sledi zgradbi slovarskih sestavkov tiskanih slovarjev. ${ }^{19} \mathrm{~V}$ nekaterih slovarskih sestavkih so sicer izkoriščene določene medleksemske povezave, poleg tega pa pojasnila v pojavnih okencih ob kazalcu miške ${ }^{20}$ pripomorejo $\mathrm{k}$ temu, da je slovar dovolj razumljiv in informativen tudi za splošnega uporabnika.

Prvi slovenski dialektološki korpus, Govorni korpus Koprive na Krasu GOKO (Šumenjak, Vičič, 2013), ${ }^{21}$ je bil najverjetneje tudi prvi spletni dialektološki vir, ki je vključeval zvočne posnetke narečnega govora. Korpus vsebuje okoli 60 minut posnetega gradiva (Šumenjak, 2013, str. 35), razdeljenega na krajše posnetke; govorjeno besedilo je prikazano v fonetični in poenostavljeni transkripciji ter poknjiženem zapisu. Ob objavi je korpus predstavljal sodoben in svež pristop k predstavitvi narečnega gradiva širši javnosti, vendar se z

17 Slovar vključuje leksiko s področja kmetijstva, ki je bila zbrana v štirih krajevnih govorih koroškega podjunskega narečja, in je ob objavi predstavljal »[p]rvi model za izdelavo strokovnega jezikovnega (slikovnega) narečnega slovarja (Benko, 2016, str. 135).

18 Uporabniku se ob izbiri določene črke prikažejo vsa gesla, ki se z njo začnejo, s čimer pridobi boljši vpogled v nabor uslovarjene leksike. Na portalu Fran lahko lekseme v izbranem slovarju iščemo le s klikanjem skozi slovarske strani ali pa s pomočjo iskalne vrstice (to je v primeru iskanja po narečnem slovarju velikokrat nepraktično, saj kljub predlogom v spustnem meniju iskalne vrstice ne moremo vnaprej vedeti, kateri leksemi so vključeni v slovar).

19 Za glasovno poknjiženim geslom in narečno ustreznico so linearno nanizani slovnični razdelek, razdelek s krajevnimi označevalniki, pomen in morebitne sopomenke, spodaj pa še narečno ponazarjalno gradivo in etimološki razdelek, kar pri krajših sestavkih pušča precej neizkoriščenega prostora v oknu brskalnika. Številna grafična znamenja, prvotno namenjena racionalizaciji prostora v tiskanih slovarjih, so s sodobnimi spletnimi oblikovalskimi rešitvami v veliki meri postala odveč. V tem oziru slovar oblačilnega izrazja bolje izkorišča potencial medija, v katerem je objavljen.

20 Npr. poimenovanja posameznih razdelkov slovarja, poimenovanja raziskovalnih točk.

21 Benko (2016, str. 127) je korpus GOKO zabeležila kot enega od trinajstih slovenskih spletnih narečnih slovarjev (dialektoloških in ljubiteljskih). Med naštetimi so trije delo dialektologov in še vedno delujejo: korpus GOKO, Narečna bera in Mali bisidnik za tö jošt rozajanskë pïsanjë (zdaj Resianica; Steenwijk, 2004). 
vidika sodobnih jezikovnih tehnologij že kažejo številne možnosti za izboljšave, npr. izvedba iskanja in določanja iskalnih pogojev. ${ }^{22}$ Podobno velja tudi za Govorni korpus Ospa - GOSP (Šumenjak, Vičič, 2013), ki je bil pripravljen po zgledu korpusa GOKO.

\subsection{Spletne aplikacije}

Spletne narečne aplikacije med vsemi spletnimi dialektološkimi jezikovnimi viri najbolje izkoriščajo možnosti, ki jih nudi digitalno okolje (npr. združevanje jezikovnih podatkov s kartografskimi, vnos povezav na druge jezikovne vire, vzpostavljanje medleksemskih povezav med narečnim gradivom, dodajanje slikovnega, zvočnega in video ponazarjalnega gradiva, urejanje uporabniških vlog in odnosov med njimi), hkrati pa se od ostalih spletnih virov razlikujejo po tem, da lahko uporabnik kot skrbnik sam ustvarja in oblikuje nove vsebine, torej za razliko od virov v podpoglavju 2.1 govorimo ne le o virih, temveč tudi o orodjih. ${ }^{23}$ Zaenkrat v slovenskem prostoru obstajajo tri tovrstne aplikacije - narečni atlas, interaktivna karta narečnih besedil in narečni slovar -, ki so predstavljene v nadaljevanju. ${ }^{24}$

22 Glavna pomanjkljivost je ta, da splošni uporabnik vnaprej ne ve, katere besede so vključene v korpus, zato lahko brez jasnih in dostopnih navodil do gradiva pride le z naključnim vpisovanjem besed v iskalno vrstico. Ker je korpus nastal v pilotni raziskavi (Šumenjak, 2013, str. 35) in gre za prvi tovrstni prikaz narečnega gradiva na Slovenskem, so njegove tehnične omejitve razumljive.

23 S podrobnim razmejevanjem med vrstami aplikacij se nisva ukvarjala. Narečna bera denimo temelji na sistemu za upravljanje vsebin Joomla, kar jo uvršča med spletne aplikacije, vendar je med Narečno bero in v nadaljevanju predstavljenim SSOLP mogoče opaziti veliko razliko v zasnovi, ki se odraža zlasti v funkcionalnostih aplikacije. SSOLP ima namreč tudi skrbniški del vmesnika, ki uporabniku omogoča enostaven vnos novih vsebin.

24 V nastajanju so še tri spletne aplikacije - interaktivni Slovenski lingvistični atlas (Škofic in Vičič, 2013), Frazeograf (Mrvič in Žnidaršič, 2020) in Narečni frazem (Mezgec idr., b. 1.). Interaktivni Slovenski lingvistični atlas (e-SLA) je spletna različica Slovenskega lingvističnega atlasa. Temeljil bo »na medsebojni povezanosti različnih podatkovnih zbirk « (Škofic, 2013, str. 98) - uporabnik bo namreč lahko prek »jezikovne karte dostopal do digitaliziranega arhivskega gradiva, zvočnih in video posnetkov v podatkovni zbirki ter do drugih spletnih povezav na bibliografske podatke o raziskavah krajevnega govora [...] ter na podatke o krajih - točkah iz raziskovalne mreže jezikovnega atlasa « (prav tam, str. 96). Zaenkrat sta oblikovani interaktivni karti za besedi kmetija in hiša (Bon, 2018, str. 49). Frazeograf, ki bo na voljo od konca letošnjega leta dalje, je prostodostopna, odprtokodna, interaktivna in rastoča aplikacija za ustvarjanje in urejanje frazeološkega gradiva (Mrvič, 2020). V njej je bil leta $2020 \mathrm{v}$ okviru magistrskega 


\section{APLIKACIJE SNA, IKNB IN SSOLP}

\subsection{Slovenski narečni atlas (SNA)}

SNA je v sklopu interaktivnih aplikacij, ki omogočajo vnos in organizacijo podatkov na podlagi jezikovnih kart, v svojem magistrskem delu podrobneje predstavila Mija Bon (2018), ${ }^{25}$ in sicer skupaj z interaktivnim Slovenskim lingvističnim atlasom, ki je spletna različica Slovenskega lingvističnega atlasa (SLA), in IKNB (gl. podpoglavje 3.2). Aplikacija SNA je nastajala in se razvijala pod mentorstvom Alenke Kavčič (FRI); leta 2017 jo je v okviru diplomskega dela izdelal Gregor Šajn, leto pozneje pa jo je nadgradil Nermin Jukan. ${ }^{26}$ Dialektološko vsebino aplikacije so pod mentorstvom Vere Smole na terenu zbrali, geolingvistično obdelali in vnesli študenti Oddelka za slovenistiko. V osnovi SNA izpolnjuje temeljne pogoje, ki jih za predstavitev prostorske razširjenosti (na zemljevidih) posameznih jezikovnih pojavov potrebuje geolingvistika. Splet je jezikovnim virom omogočil dodatne funkcije, ki pripomorejo k natančnejšemu raziskovanju in večji informativnosti, zaradi česar se je tudi Bon odločila za vnos narečnega frazeološkega gradiva (primerjalnih frazemov s pomenom človeške lastnosti) v SNA, skupaj s komentarji in povezavami na druge vire (Bon, 2018, str. 28, 48). Vsebino aplikacije sta v zaključnih delih pomagali nadgraditi tudi Keržič (2017) in Poljanšek (2019).

\subsubsection{Kaj aplikacija omogoča uporabnikom}

SNA je spletno orodje, ustvarjeno za kartiranje narečne leksike iz različnih tematskih polj (trenutno zapolnjeno polje so primerjalni frazemi, deloma poimenovanja delov stare kmečke hiše in sadja, temi nekonvencionalnih replik in posode pa sta le nakazani). Osrednji element aplikacije je enaka narečna karta kot pri IKNB z jasno prikazanimi narečnimi skupinami, narečji in podnarečji.

dela ustvarjen poskusni narečni frazeološki slovar, ki ga je pod mentorstvom Vere Smole (FF) izdelal Rok Mrvič. Narečni frazem je pilotna spletna aplikacija (Vičič in Marc Bratina, 2015, str. 814); funkcionalnosti aplikacije so torej zaenkrat v celoti na voljo le sodelavcem projekta, ki so hkrati registrirani uporabniki. Izdelana aplikacija bo prostodostopna in bo »skupnosti pomagala pri zbiranju narečnih frazemov « (prav tam, str. 817), na ta način pa bi se sčasoma lahko oblikoval vseslovenski narečni frazeološki e-slovar (prav tam, str. 812).

25 Avtorica je magistrsko delo pripravila pod mentorstvom Vere Smole (FF).

26 Podrobni podatki o Šajnovem diplomskem delu se nahajajo na seznamu literature. Jukan je aplikacijo nadgradil pri predmetu Računalništvo v praksi II. 
SNA je torej namenjen spoznavanju slovenske narečne leksike, vendar je njegov vmesnik za razliko od IKNB (podpoglavje 3.2) in SSOLP (podpoglavje 3.3) za uporabnika nejezikoslovca precej zahtevnejši in manj intuitiven. Od njega namreč pričakuje temeljno geolingvistično znanje o uporabi jezikovnih kart, ki omogoča branje podatkov s karte in priložene legende, ter poznavanje fonetične transkripcije, v kateri je zapisano vse narečno gradivo. Za večjo jasnost izhodiščne narečne karte bi morala aplikacija ponujati možnost dodatne legende ali preglednega seznama na karti obarvanih območij, ki predstavljajo narečne skupine, narečja in podnarečja. Do podatkov o teh območjih lahko uporabnik trenutno dostopa le s klikom na izpisane raziskovalne točke. Zaradi naštetega je aplikacija najbolj zanimiva za študente in jezikoslovce.

Uporabniku se ob izbiri tematskega polja v prvem spustnem meniju in leksema, navedenega v drugem spustnem meniju (Slika 1), prikažejo podatki o prostorski razširjenosti izbranega leksema, saj se izpišeta število in geografski položaj raziskovalnih točk, kjer je bil leksem zabeležen (zvočni zapis in fonetična transkripcija), desno od narečne karte pa je za interpretacijo rezultatov dodana tudi legenda znakov, uporabljenih za diferenciacijo gradiva. Legenda vsebuje glasovno poknjiženi ${ }^{27}$ leksem s pripadajočim simbolom, ki se na karti pojavlja skupaj s kratico kraja. Simbolom je za jasno diferenciacijo narečnega gradiva na karti mogoče spreminjati obliko in barvo. Bon kot eno izmed pomembnih prednosti SNA navaja zlasti možnost oblikovanja lastnega nabora na karti prikazanih leksemov, ki ga ustvarimo z obkljukanjem želenih leksemov v legendi (2018, str. 54). To uporabniku omogoča ciljno brskanje in organizacijo narečnega gradiva z uporabo besedotvornih in/ali morfoloških kriterijev.

Ob kliku na izpisano raziskovalno točko, označeno s simbolom in kratico kraja, se odpre novo okno, ki vsebuje podatke o kraju, narečno umestitev govora ter glasovno poknjiženi leksem v slovarski obliki, ki mu je dodana fonetična transkripcija, na priloženem vtičniku pa lahko uporabnik posluša zvočni zapis leksema - slednji je lahko naveden samostojno ali znotraj daljšega besedilnega zgleda.

27 Pod pojmom glasovna poknjižitev »je mišljen prenos glasovnega sistema narečnega govora v knjižnega, na vseh drugih jezikovnih ravninah pa je ohranjen narečni sistem « (Smole, 2019, str. 25). 
Poleg navedenih možnosti je h karti mogoče priložiti PDF datoteko komentarja in morebitno slikovno gradivo (fotografijo ali ilustracijo). Obe možnosti znatno povečata informativnost izpisa in uporabniku ponudita celovitejšo informacijo o iskanem narečnem gradivu.

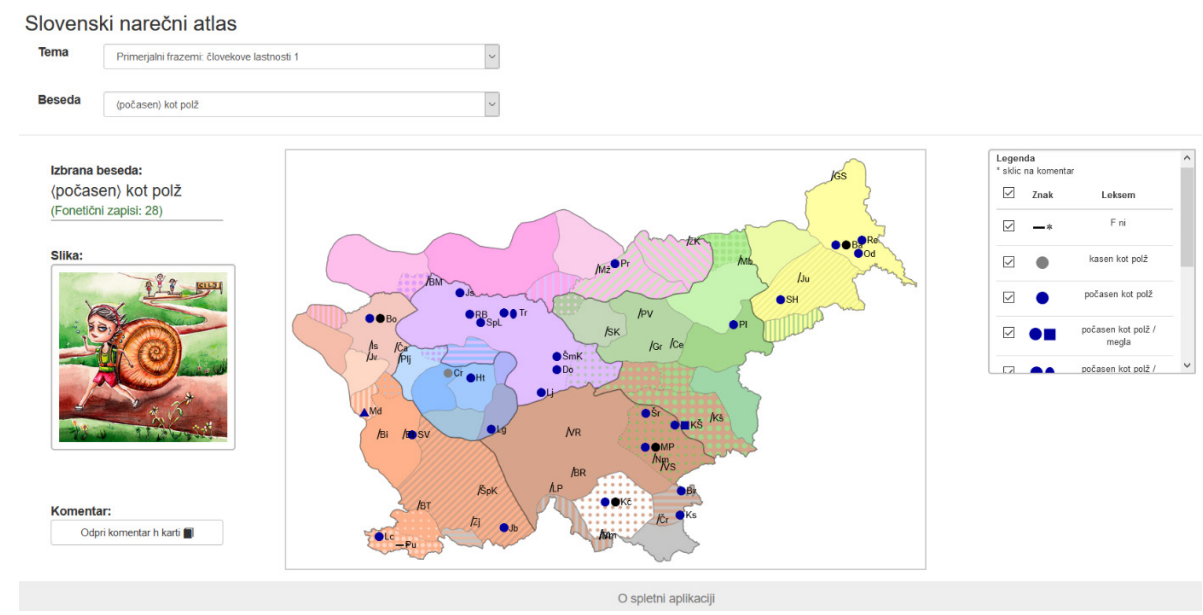

Slika 1: Geolingvistični prikaz primerjalnega frazema (počasen) kot polž.

\subsection{Interaktivna karta slovenskih narečnih besedil (IKNB)}

Aplikacijo je leta 2018 v okviru diplomskega dela izdelal Ivan Lovrić, študent FRI, ${ }^{28}$ še istega leta pa jo je nadgradil Nermin Jukan, ${ }^{29}$ prav tako študent FRI. Vsebina prve različice aplikacije je nastala na podlagi brošure Stara kmečka hiša: Narečna besedila z analizo I (Smole in Horvat, 2016). IKNB tako vsebuje narečna besedila (posnetke, fonetične in poknjižene prepise ter analize govorov) na temo stare kmečke hišs ${ }^{30}$ (prostori in oprema v njej). Večino gradiva so zbrali in pripravili študenti Oddelka za

28 Lovrić je aplikacijo izdelal pod mentorstvom Alenke Kavčič (FRI) in somentorstvom Vere Smole (FF). Podrobni podatki o diplomskem delu se nahajajo na seznamu literature.

29 Jukan je izdelano aplikacijo nadgradil z dodatnimi funkcionalnostmi pri predmetu Računalništvo v praksi I, in sicer pod mentorstvom Alenke Kavčič.

30 Izhodiščno besedilo v knjižnem jeziku Stare kmečke hiše je po delu vprašalnice za SLA, ki jo je sestavil Fran Ramovš, pripravila Vera Smole. Dostopno je na spletni strani IKNB, pod zavihkom $\mathrm{O}$ aplikaciji. 
slovenistiko $\mathrm{FF}^{31}{ }^{31} \mathrm{~V}$ rastočo ${ }^{32}$ aplikacijo je trenutno vključenih sto krajevnih govorov.

Osnovo aplikacije predstavlja Karta slovenskih narečij, ${ }^{33}$ na kateri so z različnimi barvami in vzorci predstavljene vse narečne skupine, narečja in podnarečja, ter pripadajoča legenda. Karta je zgrajena na odprtokodni Javascriptovi knjižnici Leaflet in prostodostopnih zemljevidih OpenStreetMap (Kavčič idr., 2018, str. 122), njena uporaba pa je enostavna - povečuje in pomanjšuje se skupaj z zemljevidom. Na karti so z ikonami in kraticami označeni kraji, ${ }^{34}$ katerih govori so vključeni v aplikacijo.

\subsubsection{Kaj aplikacija omogoča uporabnikom}

IKNB je spletno orodje za spoznavanje slovenskih narečij, namenjeno tako dialektologom kot širši javnosti. Zasnovano je tako, da uporabnikom omogoča jasen pregled nad celotnim sistemom razdelitve slovenskih narečij in natančnejšo predstavitev posameznih krajevnih govorov na več ravneh; ker so govori predstavljeni na enak način, jih ni težko primerjati med sabo.

Vsaka narečna skupina je na zemljevidu označena s svojo barvo, vsako narečje in podnarečje pa vsebuje dodatne grafične simbole (pike ali poševne črte), kar uporabnikom omogoča, da spoznavajo stike in medsebojne vplive narečij in podnarečij (Kavčič idr., 2018, str. 122). Uporabniki lahko razdelitev

31 Zvočne posnetke, fonetične transkripcije in poknjižitve besedil so pripravili študenti, ki so do leta 2018 obiskovali izbirni predmet Slovenska narečja pod vodstvom Vere Smole in Mojce Kumin Horvat (ZRC SAZU, ISJFR), analize pa študenti seminarja pri predmetu Slovenska dialektologija in izbirnega predmeta Poglavja iz zgodovine slovenskega glasoslovja, po letu 2018 pa tudi drugih predmetov, pod vodstvom Vere Smole.

32 Ustvarjalci aplikacije poleg dodajanja novih krajevnih govorov pod temo Stara kmečka hiša načrtujejo razširitve z dodajanjem novih besedil in novimi temami. Vključiti želijo dve basni (Čebela in Čmrlj ter Mravlji), ki sta krajši in manj zahtevni besedili kot besedilo o stari kmečki hiši, s čimer bi se mladim najverjetneje bolj približali in jih pritegnili k uporabi aplikacije. Za razliko od besedil o kmečki hiši besedila basni ne bi vključevala diahrone analize, ampak sinhrono primerjavo s knjižnim jezikom (Smole, 2019, str. 25-27).

33 Karta je nastala na podlagi Dialektološke karte slovenskega jezika Frana Ramovša (1931), novejših raziskav in gradiva Inštituta za slovenski jezik ZRC SAZU. Priredili so jo Tine Logar in Jakob Rigler (1983), Vera Smole in Jožica Škofic (2011) ter sodelavci Dialektološke sekcije ISJFR ZRC SAZU (2016).

34 Postavitev ikone, ki predstavlja posamezni kraj, je »določena z geografskimi koordinatami (geografsko dolžino in širino) kraja « (Kavčič idr., 2018, str. 123). 
slovenskih govorov na narečne skupine, narečja in podnarečja spoznajo in usvojijo na dva različna načina.

1. Ko se s kazalcem miške premaknejo na neko narečno območje, se to obrobi z odebeljeno rdečo črto, v spodnjem delu zaslona pa se prikaže bel okvirček s poimenovanjem narečja in narečne skupine, pa tudi podnarečja, če se nahajajo na območju podnarečja (Slika 2). Če se s kazalcem postavijo na ikono s kratico nekega kraja, se zgodi podobno; v spodnjem delu zaslona se prikaže bel okvirček s podatki o narečju, podnarečju in narečni skupini, spredaj pa je dodano še ime kraja.

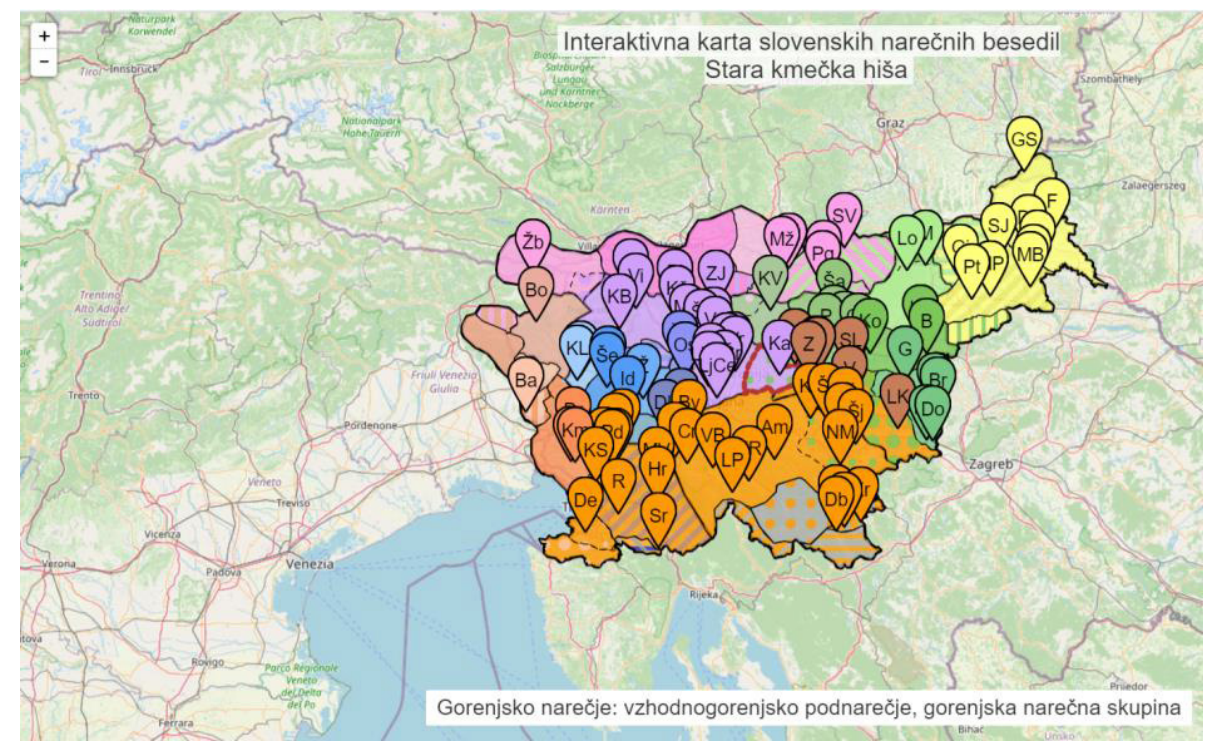

Slika 2: Naslovna stran IKNB s kazalcem miške na območju vzhodnogorenjskega podnarečja.

2. Uporabniki si pri spoznavanju delitve slovenskih narečij lahko pomagajo tudi z legendo. Ko se s kazalcem miške postavijo na določen zapis (narečna skupina, narečje, podnarečje) v legendi, se ta zapis obarva rdeče, pripadajoče območje na karti pa se obrobi z odebeljeno rdečo črto.

Aplikacija omogoča poljubno premikanje po zemljevidu in približevanje, kar je še posebej praktično, kadar je na manjšem območju označenih več krajev (Slika 3); s približevanjem se tako lahko posamezne posnetke lažje loči med seboj (Kavčič idr., 2018, str. 122). 


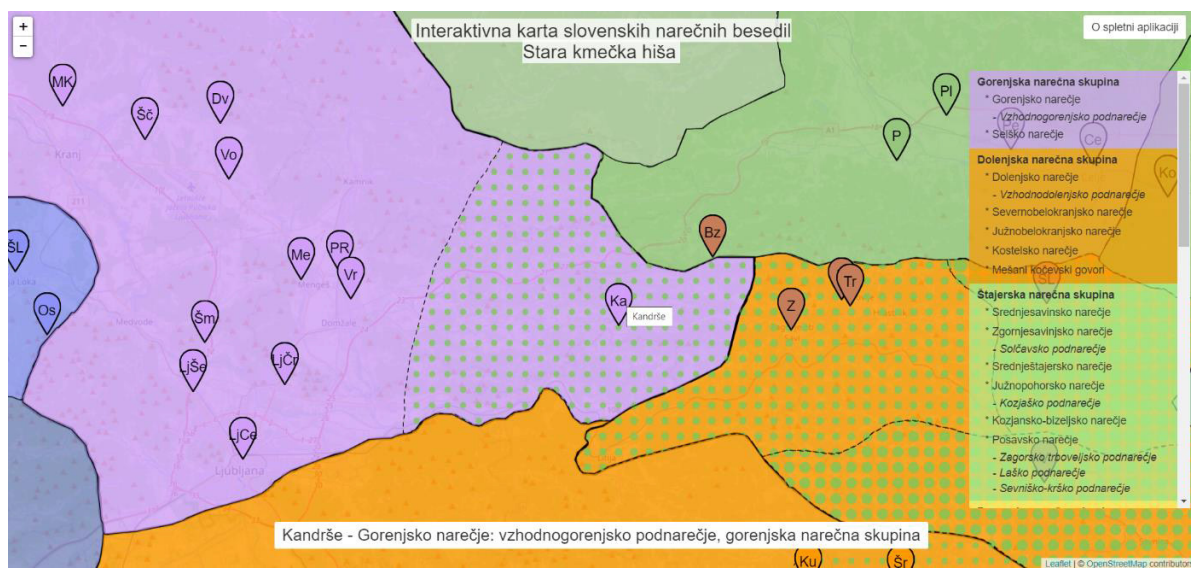

Slika 3: Povečava naslovne strani IKNB s kazalcem miške na ikoni kraja Kandrše.

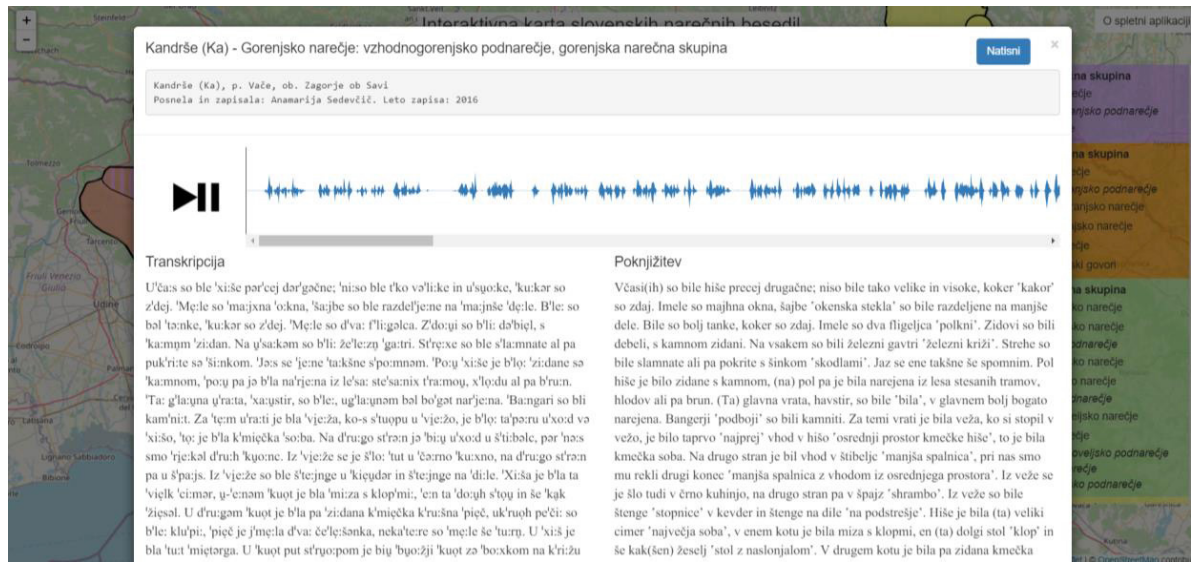

Slika 4: Primer pojavnega okna ob kandrškem krajevnem govoru.

Obiskovalci spletne strani lahko krajevne govore, vključene v aplikacijo, spoznajo na več ravneh. Ko kliknejo na določeno ikono s kratico kraja, se odpre pojavno okno (Slika 4). To v zgornjem delu vsebuje poimenovanje kraja in kratico, uporabljeno na karti, ter podatke o narečju, podnarečju in narečni skupini. Sledijo podrobnejši podatki o kraju (pod katero pošto in v katero občino spada) ter podatki o avtorju posnetka, zapisovalcu in letu zapisa. Osrednji del v vsakem pojavnem oknu predstavljajo zvočni posnetek ${ }^{35}$ narečnega bese-

35 Zaradi boljše uporabniške izkušnje je valovanje zvoka prikazano grafično, omogočeno pa je tudi premikanje nazaj in naprej po posnetku (Kavčič idr., 2018, str. 124). 
dila ter njegova fonetična transkripcija in glasovna poknjižitev, ki se nahajata pod posnetkom. Pri nekaterih krajih je dodana tudi diahrona analiza govora (Smole, 2019, str. 25) z vidika značilnosti na sedmih jezikovnih ravninah (naglas, dolgi samoglasniki, kratki naglašeni in kratki nenaglašeni samoglasniki, soglasniki, oblikoslovni pojavi, leksika) (Kavčič idr., 2018, str. 123-124).

\subsection{Slovar starega orodja v govoru Loškega Potoka (SSOLP)}

Slovar je nastal leta 2018 v okviru štirimesečnega Študentskega inovativnega projekta za družbeno korist (ŠIPK), pri katerem so kot osrednje partnerske organizacije sodelovale FF, FRI, NTF in OŠ dr. Antona Debeljaka Loški Potok. ${ }^{36}$ Študenta FRI pod mentorstvom Alenke Kavčič sta izdelala aplikacijo, študentki NTF pod mentorstvom Helene Gabrijelčič Tomc sta posneli in uredili video in foto gradivo ter ustvarili celostno grafično podobo aplikacije, ${ }^{37}$ študenti FF pod mentorstvom Vere Smole pa so poskrbeli za vsebino slovarja (na terenu so posneli gradivo in ga uredili ter zasnovali in izdelali slovarske sestavke).

SSOLP je narečni ${ }^{38}$ tematski slovar. V okviru širše teme staro orodje vključuje podtemi orodje za sekača in tesača ter orodje za spravilo sena, na ta način pa so v slovarju zbrani izrazi za orodja in pripomočke tistih opravil, ki so v Loškem Potoku najbolj prisotna. ${ }^{39}$ Poleg izrazov za orodja so v slovar vključena tudi poimenovanja za sestavne dele orodja in sopojavnice, to so »besede, ki se najpogosteje pojavljajo v sobesedilu« (Kenda-Jež v Smole idr., 2020, str. 1043); v konkretnem primeru so bili to glagoli z istim korenom, kot jih imajo

36 Podrobnosti o projektu so predstavljene na spletni strani SSOLP, pod zavihkom O projektu.

37 Oblikovalski vidik slovarja in izvedbeni vidik slovarja vključno z zasnovo in zgradbo slovarja ter skrbniškim in nadskrbniškim delom aplikacije sta predstavljena v Smole idr. (2020). Skrbniški del aplikacije omogoča dodajanje novih ali urejanje že naloženih vsebin, nadskrbniški del pa dodajanje novih ali urejanje že registriranih skrbnikov aplikacije - nadskrbnik torej ne more posegati v vsebine aplikacije.

38 Slovar vsebuje besedje krajevnega govora Loškega Potoka. V občini Loški Potok se govorita dve narečji: v severnem delu občine z osrednjim Hribom in okoliškimi vasmi Mali Log, Retje, Šegova vas in Travnik se govori krajevni govor tonemskega dolenjskega narečja, v južnem delu pa netonemsko kostelsko narečje. V raziskavo je bil vključen le tonemski govor Loškega Potoka, ki v SLA še ni zajet, njegove osnovne značilnosti pa so že predstavljene (gl. Smole idr. 2020, str. 1041-1042).

39 V okviru projekta je bilo zbranega ogromno narečnega gradiva, vendar sta podtemi zaenkrat zapolnjeni le delno, toliko, kot je bilo možno v omejenem času trajanja projekta. 
orodja (npr. kosa - kositi), in samostalniki za izvajalce (npr. kosec). Slovenisti so narečno gradivo zbrali ${ }^{40} \mathrm{~s}$ prostimi pogovori, pomagali pa so si tudi z usmerjevalnimi vprašalnicami Francke Benedik in Vere Smole ter z orodji in pripomočki informatorjev. Rastoči slovar omogoča dopolnjevanje obeh obstoječih tem in dodajaje novih. ${ }^{41}$

\subsubsection{Kaj aplikacija omogoča uporabnikom}

SSOLP je uporaben za vse, ki si želijo izvedeti več o lokalni snovni (starejša orodja in vsakdanji pripomočki) in nesnovni (narečni govor) kulturni dediščini. Uporabnikom se za iskanje po slovarju vanj ni treba prijaviti, po slovarju pa lahko brskajo na več načinov. 1) Želeni leksem lahko vpišejo v iskalno vrstico (leksem je mogoče tudi izbrati iz spustnega menija) ali pa 2) najprej v zavihku Stara orodja izberejo podtemo, nato pa iz nabora izpisanih gesel s klikom na določeno geslo odprejo slovarski sestavek. 3) Ko uporabniki kliknejo na izbrano geslo in se jim odpre slovarski sestavek, lahko prosto prehajajo med ostalimi gesli in njihovimi slovarskimi sestavki, saj so med njimi vzpostavljene medleksemske povezave.

Uporabniki lahko uslovarjene lekseme spoznajo z več vidikov. Naslovne strani slovarskih sestavkov so grafično razdeljene na dva dela (gl. primer gesla plenkača na Sliki 5):

1. Na levi je najprej naslov - geslo v glasovno poknjiženem zapisu (a) $\mathrm{s}$ fotografijo (b), spodaj pa so ikone, ki ob kliku odprejo prikaz fotografij, videoposnetkov in zvočnih posnetkov (c). Z izjemo gesla je leva stran slovarskega sestavka v celoti namenjena ponazarjalnemu gradivu.

2. Na desni strani se nahaja besedilni, tj. jezikoslovni del slovarskega sestavka, ki pri vseh geslih vsebuje naslednje podatke: geslo v glasovno poknjiženem zapisu (d), slovarsko obliko narečnega leksema (e) z rodilniško končnico (f) (oboje je zapisano v fonetični transkripciji) in

40 Raziskovalci so obiskali 24 informatorjev. V slovar je zaenkrat vključeno le gradivo, pridobljeno pri Jožetu Anzeljcu (p. d. Štalarjevem stricu) iz Malega Loga (Smole idr., 2020, str. 1040).

41 Iz tematskega slovarja bo postopoma mogoče razviti splošni narečni slovar s prikazom slovarskih sestavkov po abecednem zaporedju. Nadgradnja aplikacije je v teku, namenjena pa bo Loškopotoškemu slovarju oz. Slovarju govora Loškega Potoka. 
besednovrstno oznako (slovnični spol samostalnika) ${ }^{42}$ (g) ter pomen leksema (h). Gre za t. i. obvezne razdelke, ki so ob vseh geslih zapolnjeni. Poleg obstojskega (d), izgovarjalnega (e), slovničnega (f), besednovrstnega (g) in pomenskega razdelka (h), ki se nahajajo v desnem, besedilnem delu slovarskega sestavka, je za vzpostavitev slovarskega sestavka obvezen tudi ponazarjalni razdelek (b, c) (fotografija ter zvočni posnetek in/ ali videoposnetek). Nekaterim geslom so dodani podatki o izvoru leksema (i) ter medleksemske povezave (j), ki uporabniku ponudijo podatke o morebitni sopomenki, o tem, ali ima izhodiščno orodje več sestavnih delov, ali obstaja več vrst tega orodja, s katerimi orodji ga lahko vzdržujemo, ali ima geslo nadpomenko in kateri leksemi z istim korenom so vključeni v slovar. Vsi ti podatki so del t. i. neobveznih razdelkov, ki so ob nekaterih geslih zapolnjeni, ob nekaterih pa ne. Neobvezni so torej etimološki (i) in sopomenski razdelek ter pet povezovalnih razdelkov (j): vrste (orodja), nadpomenke, sestavni deli (orodja), orodja (za vzdrževanje) in besedje z istim korenom (Smole idr., 2020, str. 1044-1046).

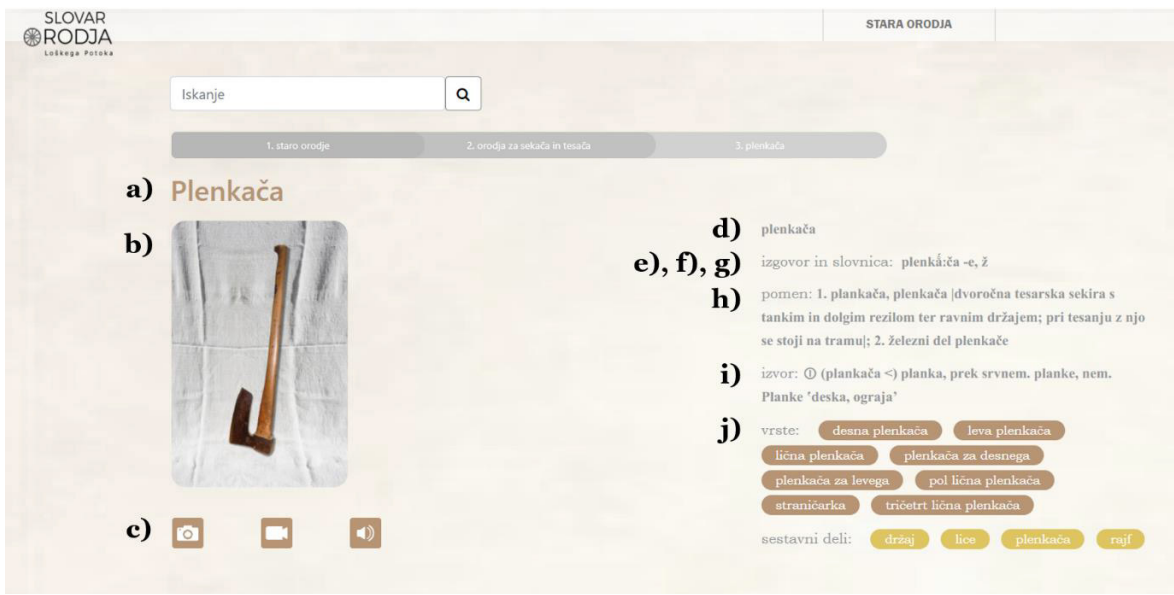

Slika 5: Prikaz naslovne strani slovarskega sestavka za geslo plenkača.

42 V SSOLP je tako kot v Narečni beri pri samostalniških geslih izpisana rodilniška končnica in dodana oznaka za besedno vrsto oz. spol samostalnika; v obeh slovarjih je izvedba slovnično-besednovrstnih razdelkov podobna tudi pri sestavkih pridevniških in glagolskih gesel. Poleg tega etimološki razdelek v SSOLP, ki je v izpisu poenostavljeno poimenovan izvor, uvaja simbol (I), ki ga uporablja tudi Benko. Oboje je odraz zgledovanja po oblikovanju slovarske mikrostrukture v prvotno tiskanih slovarjih. 
Leksemi, ki so vključeni v sopomenski razdelek (v slovarju: sopomenke) in $\mathrm{v}$ povezovalne razdelke ( $\mathrm{v}$ slovarju: vrste, nadpomenke, sestavni deli, orodja in besedje $\mathrm{z}$ istim korenom), so zapisani v barvnih okvirčkih. Gre za medleksemske povezave, s katerimi je uporabnikom slovarja omogočeno raziskovanje besedja loškopotoškega govora v več smereh; ob kliku na določen okvirček (npr. desna plenkača) uporabnik pride do novega slovarskega sestavka, ki pripada geslu, na katerega je kliknil (v tem primeru geslu desna plenkača). Z medleksemskimi povezavami so ustvarjalci slovarja želeli kar najbolje izkoristiti potencial elektronskega medija in na ta način uporabnikom omogočiti čim bolj dinamično in nelinearno raziskovanje po slovarju (Smole idr., 2020, str. 1045).

Ko uporabnik klikne na ikono kamere ali zvočnika, se mu odpre druga stran slovarskega sestavka, ki vsebuje videoposnetek ali zvočni posnetek. Ob njem se v stolpcu Narečno prikaže zapis govorjenega besedila v fonetični transkripciji, v stolpcu Knjižno pa prevod v knjižni jezik. ${ }^{43}$ Na Sliki 6 je prikazan pogled uporabnika, ko ob geslu plenkača klikne na ikono kamere.

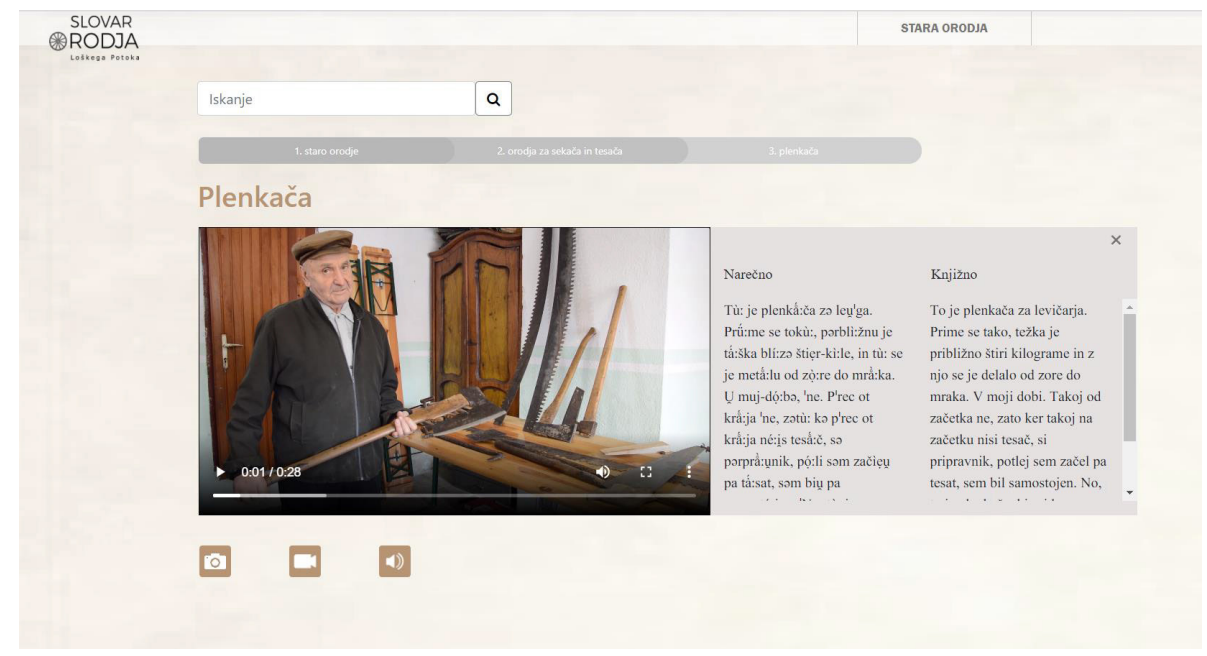

Slika 6: Prikaz videoposnetka in zapisa govorjenega besedila ob slovarskem geslu plenkača.

43 Narečni sistem je v knjižnega prenesen na vseh jezikovnih ravninah (Smole idr., 2020, str. 1045). 
Aplikacije, ki jih predstaviva, omogočajo spoznavanje narečij na več ravneh: ne le pisno, kot so to doslej omogočala tiskana dialektološka dela, temveč interaktivno s ponazarjalnim slikovnim gradivom, prilagodljivimi kartografskimi podatki ter narečnimi avdio- in videoposnetki, ki uporabnikom omogočajo dostop do podatkov o slušnem vtisu. Kljub številnim prednostim, ki jih prinašata uporaba in razvoj predstavljenih aplikacij, želiva izpostaviti, da bi bilo vsako izmed njih mogoče še izboljšati, ob čemer se zavedava, da so sredstva za to omejena. Tako bi bilo v SNA dobro dopolniti obstoječa polja z novimi leksemi, posodobiti temeljno karto, dodati nove raziskovalne točke, narečno posneto gradivo vključiti ob več leksemih in poleg fonetične transkripcije dodati še poenostavljeni zapis za uporabnike brez dialektološkega predznanja, za uporabniku prijaznejšo izkušnjo pa bi bila smiselna tudi nadgradnja uporabniškega vmesnika, kot je bila letos izvedena za SSOLP. ${ }^{44} \mathrm{~V}$ IKNB bi bilo smiselno vključiti več tem, primernih za vnose krajših in strukturno preprostejših besedil, kar so avtorji začeli z zbiranjem dveh basni, ki utegneta aplikaciji prinesti dodano pedagoško vrednost v osnovnošolskem učnem procesu pri seznanjanju učencev s slovenskimi narečnimi govori. IKNB izmed obravnavanih treh aplikacij pokriva največje število raziskovalnih točk oz. krajev, kjer so bili zbrani narečni posnetki, vendar kljub temu ostajajo slabše zapolnjena ali nezapolnjena območja, kjer bodo dobrodošli novi vnosi zvočnih posnetkov s pripadajočimi fonetičnimi prepisi, poknjižitvami prepisov in analizami govorov. SSOLP bi bilo treba dopolniti z novimi slovarskimi sestavki in fotografskim gradivom ob že obstoječih. Na ta način bi aplikacije, podobno pa tudi ostale spletne dialektološke vsebine, zares rasle in se nadgrajevale. Ob tem želiva v širšem kontekstu slovenskih spletnih dialektoloških virov dodati, da bi bilo treba metapodatke slovarjev

44 Najnovejšo nadgradnjo spletne aplikacije SSOLP je v času nastajanja tega besedila opravil Dimitrije Mitić v okviru diplomskega dela. Skrbniški del aplikacije je zdaj bolj intuitiven in uporabniku prijazen: slikovno gradivo v tabelah je opremljeno z možnostjo predogleda slik, ki jih je mogoče tudi povečati; dodano je modalno okno za ustvarjanje povezave med geslom in medijskimi vsebinami, ki bodo služile kot ilustrativno gradivo; ilustrativno gradivo je mogoče prostorsko razmeščati in urejati vrstni red prikaza; medleksemske povezave je mogoče poljubno ustvarjati ter jih oblikovno in vsebinsko prilagajati slovarskim podatkom; zelo pomembna je tudi prilagoditev vmesnika za nemoteno delovanje aplikacije na namiznih in mobilnih napravah (gl. Mitić, 2021). 
in orodij na spletnih mestih jasno izpostaviti, s čimer bi omogočili ustrezno citiranje jezikovnih virov in s tem sledljivost podatkov ter ponovljivost rezultatov raziskav. Poleg objave celovitih metapodatkov bi bilo jezikovnim virom koristno dodati trajne enkratne identifikatorje za nedvoumno identifikacijo, kot priporočajo sodobne smernice na področju citiranja jezikovnih virov (Lenardič idr., 2020, str. 22).

Osrednje težave za razvoj aplikacij ne vidiva v pomanjkanju idej ali v kakovosti njihove izvedbe, temveč predvsem v kratkoročnosti projektov. Objave (npr. Škofic, 2013; Vičič in Marc Bratina, 2015; Benko, 2016; Smole, 2019) kažejo, da so slovenski dialektologi dobro seznanjeni z novostmi doma, v določeni meri tudi z novostmi v tujini, vendar je razvoj jezikovnih tehnologij, namensko razvitih za dialektološko rabo, počasen in v veliki meri odvisen od pilotnih projektov posameznikov in njihovega dela, ki v večini primerov, predstavljenih v podpoglavjih 2.1 in 2.2, poteka ali v okviru študentskih zaključnih del ali priložnostnih fakultetnih projektov. Takemu delu za dolgoročne uspehe in dosego ciljev manjka ustrezna in trajna institucionalna podpora, ki edina utegne vzdrževati izhodiščno vizijo in v končni fazi ponuditi jezikovni oz. dialektološki vir, kot je bil načrtovan, ${ }^{45}$ ter ga nadalje razvijati glede na uporabniške potrebe. ${ }^{46}$ Pri tem so lahko v veliko pomoč mehanizmi množičnega zunanjega izvajanja (ang. crowdsourcing), tj. pridobivanja podatkov s pomočjo množice izvajalcev (internetne javnosti), in množičnega financiranja (ang. crowdfunding), tj. pridobivanja denarne podpore nepovezanih posameznikov. ${ }^{47}$ Prvi od mehanizmov je bil doslej predviden v več pilotnih spletnih aplikacijah (prim. Vičič in Marc Bratina, 2015; Mrvič, Žnidaršič, 2020), drugi še ne. Kot predpogoj uspešne implementacije enega in drugega mehanizma vidiva predvsem razvejano promocijsko strategijo trenutno dostopnih aplikacij, kajti izkušnje študentov v njihovem lokalnem okolju in okolju osnovnih in srednjih šol, kjer

45 Ne le dosledna izvedba z zagotavljanjem potrebnih sredstev, institucionalna podpora je ključna tudi za zagotovitev (dolgo)trajnosti metapodatkov jezikovnih virov, kar je mogoče le s pomočjo za ta namen razvite računalniške infrastrukture (prim. Lenardič idr., 2020, str. 23).

46 S pomočjo podatkov, pridobljenih v okviru empiričnih raziskav (prim. Arhar Holdt, 2017), bi lahko strokovnjaki in študenti z različnih področij ponudili boljše programske rešitve in posledično omogočili kakovostnejše vnose narečnih jezikovnih podatkov.

47 Slovenski terminološki ustreznici uporabljava po terminološkem slovarju informatike (Islovar), ki je dostopen na http://www.islovar.org. 
opravljajo pedagoško prakso, kažejo, da je zelo malo ljudi seznanjenih z naštetimi aplikacijami in vsebinami, ki jih ponujajo. ${ }^{48}$

\section{SKLEP}

Z digitalizacijo in tehnološkim razvojem so številni jezikoslovni viri začeli izkoriščati prednosti, ki jih omogoča spletno okolje, mednje v slovenskem jezikoslovnem prostoru zlasti v zadnjem desetletju sodijo tudi dialektološki viri. Slednji uporabnikom - tako jezikoslovcem in študentom jezikoslovnih smeri kot širši javnosti - omogočajo hitrejši in lažji dostop do informacij o narečnih pojavih. Kljub pomanjkanju raziskav, ki bi to empirično potrdile, je na številnih spletnih mestih, predvsem na družbenih omrežjih, mogoče opaziti povečan interes javnosti za slovenska narečja (gl. op. 1).

Digitalizirani dialektološki viri, kakršnih je večina slovarjev na portalu Fran, so bili prvotno izdani v tiskani obliki, ob objavi na spletu pa možnosti medija niso izkoristili, kar uporabnikom otežuje iskanje po njih. Digitalni viri, prvotno zasnovani za splet, kakršen je npr. slovar Narečna bera, predstavljajo uporabniku prijaznejši pristop, ki bolje izkorišča možnosti spletnega okolja; v spletni slovar je npr. vključeno slikovno gradivo, zvočni posnetki, videoposnetki in $\mathrm{v}$ omejenem obsegu določene medleksemske povezave, še vedno pa slovarska mikrostruktura temelji na tiskanih slovarjih. V tem oziru

48 Zbiranje hišnih imen na Gorenjskem je primer ene izmed najuspešnejših praks, ki združuje uspešno promocijo in med drugim tudi dialektološko delo, potekala pa je v okviru več projektov od 2009 do 2016. V izvajanje projektov je bila vključena širša javnost: redno so bila organizirana srečanja z domačini, ki so prispevali narečno gradivo o hišnih imenih, vzpostavljeno pa je bilo tudi sodelovanje s 16 občinami in skoraj vsemi osnovnimi šolami v mreži 270 krajev, ki so bili vključeni v projekte. Rezultati več kot 12.00o zbranih hišnih imen so dostopni na spletni strani https://www.hisnaimena.si, raba hišnih imen pa je bila leta 2020 vpisana tudi v register nesnovne kulturne dediščine. Slednja se kaže kot pomembna motivacija številnih projektov - 2021 je bila namreč vzpostavljena spletna aplikacija Zapisi spomina (https://zapisi-spomina.dobra-pot.si), ki je namenjena deljenju informacij o nesnovni kulturni dediščini po načelu medgeneracijskega prenosa znanja. Aplikacija je uporabniku prijazna in temelji na participativni uredniški politiki, ki vključuje tako ljubiteljske uporabnike kot raziskovalce, med slednjimi zlasti etnologe, folkloriste in dialektologe. Aplikacija je zanimiva zlasti kot primer participativne platforme, ki je med drugim namenjena digitalnemu opismenjevanju najstarejših, čemur se pri razvoju dialektoloških aplikacij doslej ni namenjalo pozornosti, četudi so med informatorji na terenskem dialektološkem delu običajno najstarejši prebivalci raziskovanega območja. 
je naprednejši Slovar oblačilnega izrazja ziljskega govora v Kanalski dolini, ki vsebuje povezave na druge slovarske vire, prevode v tuje jezike in se ponaša z uporabniku prijaznejšim vmesnikom. Možnosti spletnega prikaza dialektoloških vsebin najbolje izkoriščajo spletne aplikacije, o katerih v kontekstu tega besedila govoriva kot o specializiranih jezikoslovnih oz. dialektoloških orodjih, ki zaradi prednosti digitalnega medija raziskovalcem ponujajo nove možnosti raziskovanja. Tovrstne aplikacije uporabnikom omogočajo spoznavanje narečnih govorov na več ravneh in prilagajanje prikaza narečnih vsebin v brskalniku. V slovenskem prostoru zaenkrat obstajajo tri - Slovenski narečni atlas (SNA), Interaktivna karta slovenskih narečnih besedil (IKNB) in Slovar starega orodja v govoru Loškega Potoka (SSOLP) -, ki so nastale v interdisciplinarnem sodelovanju različnih fakultet Univerze v Ljubljani ter so prostodostopne, odprtokodne, interaktivne in rastoče.

Glavni namen vseh treh aplikacij in hkrati njihova najpomembnejša skupna točka je interaktivno približati raznolikost slovenskih narečij različnim uporabnikom. Ker se v načinu predstavljanja gradiva razlikujejo, se razlikujejo tudi v tem, kateri skupini naslovnikov so namenjene, tj. v kolikšnem obsegu bodo lahko informativne. Najširšemu krogu uporabnikov je zaenkrat namenjen SSOLP - tematski narečni slovar, ki vključuje podtemi orodje za sekača in tesača ter orodje za spravilo sena. Iskanje po slovarju je preprosto, medleksemske povezave pa uporabnikom omogočajo razgibane možnosti raziskovanja narečne vsebine. V slovar je vključeno multimedijsko ponazarjalno gradivo - fotografije, zvočni posnetki in videoposnetki z dodanimi fonetičnimi prepisi govorjenih besedil in prevodi v knjižni jezik. Aplikacija je med vsemi tremi najbolj oblikovalsko dodelana, njen uporabniški vmesnik pa je bil v letu 2021 uspešno posodobljen. Jezikoslovcem in širši javnosti je namenjena tudi aplikacija IKNB, ki omogoča spoznavanje slovenskih narečij in posameznih krajevnih govorov na celotnem slovenskem jezikovnem prostoru. Vsak vključeni govor je predstavljen z zvočnim posnetkom narečne pripovedi, ki se sklada s krovno temo, v večini primerov je posnetkom dodana tudi fonetična transkripcija in glasovna poknjižitev, ponekod pa tudi diahrona analiza krajevnega govora. Trenutno so v aplikacijo vključene narečne pripovedi na krovno temo stare kmečke hiše in imajo sorodno vsebinsko strukturo, ki se opira na enoten model, kar olajša primerljivost in naredi zbrano gradivo bolj 
informativno. SNA je za uporabnika nejezikoslovca precej zahtevnejši in manj intuitiven, kot sta SSOLP in IKNB, saj od njega pričakuje temeljno geolingvistično znanje o uporabi jezikovnih kart in poznavanje fonetične transkripcije, v kateri je zapisano narečno gradivo. Aplikacija je ustvarjena za kartiranje narečne leksike iz različnih tematskih polj; trenutno prinaša predvsem primerjalne frazeme s pomenom človeške lastnosti. Kartiranim narečnim leksemom so dodani fonetični zapisi, mestoma pa tudi zvočni posnetki.

Z vsako novo spletno narečno aplikacijo spremljamo vzpostavitev novih ali vsaj nadgradnjo obstoječih pristopov k digitalni predstavitvi slovenskega narečnega gradiva. Tako tudi aplikacije, obravnavane v prispevku, predstavljajo napredek $\mathrm{v}$ slovenskem jezikoslovnem prostoru in doprinos $\mathrm{k}$ postopnemu razvoju spletnih odprtokodnih orodij na področju dialektologije. Meniva, da so za pospešitev tega procesa nujni: 1) sodelovanje znotraj in zunaj jezikoslovne stroke, da se zagotovi kakovostno in učinkovito institucionalno podporo novim dialektološkim virom, 2) upoštevanje potreb in želja jezikovnega uporabnika, ki bi moralo izhajati iz izsledkov empiričnih raziskav, ter zlasti 3) promocija spletnih dialektoloških virov in spodbujanje strokovnega dialoga s širšo javnostjo na tem področju, ki bo z vnosom kritične presoje obstoječih virov lahko odprl nove, še nepreizkušene možnosti sodobnih mehanizmov za dolgoročni razvoj.

\section{LITERAT URA}

\section{Slovarski in drugi dialektološki viri}

Lovrić, I., Jukan, N. idr. (2018). Interaktivna karta slovenskih narečnih besedil (IKNB). Pridobljeno s https://narecja.si

Nusheski, A., Mitić, D. idr. (2018). Slovar starega orodja v govoru Loškega Potoka (SSOLP). Pridobljeno s https://slovar-orodja.si

Šajn, G. idr. (2017). Slovenski narečni atlas (SNA). Pridobljeno s https://sna.si

Benko, A. (2013). Narečna bera. Pridobljeno s http://www.narecna-bera.si

Gostenčnik, J. idr. (2014). Slovenski lingvistični atlas 1. Pridobljeno s https:// fran.si/204

Gregorič, J. (2015). Kostelski slovar. Pridobljeno s https://fran.si/197

Ivančič Kutin, B. (2015). Slovar bovškega govora. Pridobljeno s https://fran. $\mathrm{si} / 196$ 
Kenda-Jež, K. (12007, ${ }^{2} 2015 /$ spletna različica 2019). Slovar oblačilnega izrazja ziljskega govora $v$ Kanalski dolini. Pridobljeno s https://fran.si/210

Kumin Horvat, M. (2018). Besedotvorni atlas slovenskih narečij: Kulturne rastline. Pridobljeno s https://doi.org/10.3986/9789610504214

Mezgec, T., Šukljan, T., \& Vičič, J. Narečni frazem. Različica o.9.1. Pridobljeno s http://frazem.famnit.upr.si

Mrvič, R., \& Žnidaršič, T. (2020). Frazeograf. Pridobljeno s https://www.frazeograf.si

Razvojna agencija Zgornje Gorenjske (RAGOR) (2013). Slovenska hišna imena. Pridobljeno s https://www.hisnaimena.si

Slovensko društvo Informatika (2001). Islovar. Pridobljeno s https://www.islovar.org

Steenwijk, H. (2004). Resianica. Pridobljeno s http://147.162.119.1:8081/resianica/ dictionaryForm.do

Škofic, J., \& Vičič, J. (2013). Interaktivni Slovenski lingvistični atlas. Pridobljeno s https://sla.zrc-sazu.si/\#v

Škofic, J. idr. (2016). Slovenski lingvistični atlas 2. Pridobljeno s https://fran.si/204

Šumenjak, K., \& Vičič, J. (2013). GOKO. Pridobljeno s https://jt.upr.si/GOKO/index.html

Šumenjak, K., \& Vičič, J. (2013). GOSP. Pridobljeno s https://gosp.upr.si/GOSP/ index.html

Tominec, I. (2015). Črnovrški dialekt. Pridobljeno s https://fran.si/194

Zavod Dobra pot (2021). Zapisi spomina. Pridobljeno s https://zapisi-spomina. dobra-pot.si

Weiss, P. (2015). Slovar govorov Zadrečke doline med Gornjim Gradom in Nazarjami $(A-H)$. Pridobljeno s https://fran.si/195

\section{Drugo}

Arhar Holdt, Š. (2017). Uporabniške raziskave za potrebe slovenskega slovaropisja: prvi koraki. V V. Gorjanc, P. Gantar, I. Kosem in S. Krek (ur.), Slovar sodobne slovenščine: problemi in rešitve (str. 136-148). Ljubljana: Znanstvena založba Filozofske fakultete Univerze v Ljubljani. Pridobljeno S http://www.dlib.si/?URN=URN:NBN:SI:DOC-21CL5BTo

Benko, A. (2016). Slovensko narečno slovaropisje: Razvoj, stanje, prihodnost. V K. Šter, M. Žagar Karer (ur.), Historični seminar 12 (str. 123-143). 
Ljubljana: Založba ZRC, ZRC SAZU. Pridobljeno s http://hs.zrc-sazu.si/Portals/o/sp/hs12/Benko.pdf

Bon, M. (2018). Geolingvistična interpretacija primerjalnih frazemov $v$ slovenskih narečjih na interaktivni jezikovni karti: Primerjalni frazemi s pomenom človeške lastnosti. Magistrsko delo. Ljubljana: Filozofska fakulteta Univerze v Ljubljani.

Ivančič Kutin, B. (2017). Gradivo za etnološko kontekstualizacijo muzejskih predmetov kot vir za jezikoslovne raziskave: študija primera. Jezik in slovstvo, 62(4), 65-79. Pridobljeno s http://www.jezikinslovstvo.com/pdf. php?part=2017|4|

Kavčič, A., Lovrić, I., \& Smole, V. (2018). Interaktivna karta slovenskih narečnih besedil. V D. Fišer in A. Pančur (ur.), Zbornik konference Jezikovne tehnologije in digitalna humanistika (str. 121-125). Ljubljana: Znanstvena založba Filozofske fakultete v Ljubljani. Pridobljeno s http://www.dlib.si/ stream/URN:NBN:SI:doc-YWTL37V1/35babaod-2fb8-4125-828a-d84827405afb/PDF

Keržič, M. (2017). Poimenovanje za sadje v mengeškem govoru. Diplomsko delo. Ljubljana: Filozofska fakulteta Univerze v Ljubljani.

Lenardič, J., Erjavec, T., \& Fišer, D. (2020). Citiranje jezikovnih podatkov v slovenskih znanstvenih objavah v obdobju 2013-2019. Slovenščina 2.o, 8(1), 1-34. Pridobljeno s https://doi.org/10.4312/slo2.0.2020.1.1-34

Lovrić, I. (2018). Interaktivna spletna aplikacija za slovenska narečna besedila. Diplomsko delo. Ljubljana: Fakulteta za računalništvo in informatiko Univerze v Ljubljani. Pridobljeno s https://repozitorij.uni-lj.si/Dokument. php?id=110326\&lang=slv

Mitić, D. (2021). Interaktivni tematski narečni slovar. Diplomsko delo. Ljubljana: Fakulteta za računalništvo in informatiko Univerze v Ljubljani. Pridobljeno s https://repozitorij.uni-lj.si/Dokument.php?id=141440\&lang=slv

Mrvič, R. (2020). Koncept narečnega frazeološkega slovarja: tiskana in elektronska oblika. Magistrsko delo. Ljubljana: Filozofska fakulteta Univerze v Ljubljani. Pridobljeno s https://repozitorij.uni-lj.si/Dokument. php?id $=135102$ \&lang $=$ slv

Poljanšek, S. (2019). Geolingvistična predstavitev nekaterih primerjalnih frazemov za semantično polje človekove lastnosti in stanja v slovenskih narečjih. Magistrsko delo. Ljubljana: Filozofska fakulteta 
Univerze v Ljubljani. Pridobljeno s https://repozitorij.uni-lj.si/Dokument.php?id $=118193$ \&lang $=$ slv

Smole, V. (2019). Slovenska narečja v spletnih aplikacijah. V M. Smolej (ur.), $1919 v$ slovenskem jeziku, literaturi in kulturi. 55. seminar slovenskega jezika, literature in kulture (str. 20-30). Ljubljana: Znanstvena založba Filozofske fakultete. Pridobljeno s https://centerslo.si/wp-content/uploads /2019/06/55-SSJLK_Smole.pdf

Smole, V., Gabrijelčič Tomc, H., \& Kavčič, A. (2020). Uporaba novih medijev v narečnem slovaropisju na primeru Slovarja starega orodja $v$ govoru Loškega Potoka. Rasprave: Časopis Instituta za hrvatski jezik i jezikoslovlje, 46(2), 1039-1057. Pridobljeno s https://hrcak.srce.hr/245482

Šajn, G. (2017). Interaktivni atlas slovenskih narečnih besed. Diplomsko delo. Ljubljana: Fakulteta za računalništvo in informatiko Univerze v Ljubljani. Pridobljeno s https://repozitorij.uni-lj.si/Dokument.php?id=102633\&lang=slv

Škofic, J. (2013). Priprava interaktivnega Slovenskega lingvističnega atlasa. Jezikoslouni zapiski, 19(2), 95-111. Pridobljeno s https://ojs.zrc-sazu.si/jz/ article/view/2300

Šumenjak, K. (2013). Opis govora Koprive na Krasu na osnovi dialektološkega korpusa. Doktorska disertacija. Koper: Fakulteta za humanistične študije Univerze na Primorskem. Pridobljeno s https://repozitorij.upr.si/Dokument.php?id=12070\&lang=slv

Vičič, J., \& Marc Bratina, K. (2015). Narečni frazeološki slovar - prvi koraki. V M. Smolej (ur.), Slovnica in slovar - aktualni jezikovni opis. Obdobja 34 (str. 811-818). Ljubljana: Znanstvena založba Filozofske fakultete. Pridobljeno s https://centerslo.si/wp-content/uploads/2015/11/34_2-Vicic-Bra.pdf 


\section{THREE ONLINE APPLICATIONS ON SLOVENIAN DIALECTS}

The need for a greater presence of dialectal content on the internet and its interactive multimedia presentation, especially professionally designed dialectological sources and tools, has encouraged an interdisciplinary cooperation between various faculties of the University of Ljubljana, chiefly the Faculty of Arts and the Faculty of Computer and Information Science. This union bore fruit in 2017 and 2018 in the form of three free and open-source web applications on Slovene dialects - these are Slovenski narečni atlas (SNA, 2017), Interaktivna karta slovenskih narečnih besedil (IKNB, 2018) and Slovar starega orodja v govoru Loškega Potoka (SSOLP, 2018), which are a Slovene dialect atlas, an interactive map of Slovene dialect texts and a dictionary of old tools in the local speech of Loški Potok, respectively. The article begins with a general overview of Slovenian online dialectological resources and tools, while the second part provides a more detailed presentation of these three applications currently available to users in terms of functionality. In the discussion, the circumstances of said applications' development and the related limitations are considered, with suggestions on some possible solutions that ought to be regarded to ensure long-term development.

Keywords: Slovenian dialects, online application, dialect atlas, dialect dictionary, interactive map

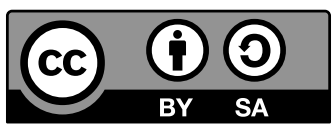

To delo je ponujeno pod licenco Creative Commons: Priznanje avtorstva-Deljenje pod enakimi pogoji 4.o Mednarodna. / This work is licensed under the Creative Commons Attribution-ShareAlike 4.0 International. 